\title{
EGYPTIAN CINEMA TREATMENT OF THE POLITICAL REALITY DURING NASSER AND SADAT ERAS
}

\author{
Naiera Shabaiek \\ Radio and Television Department-Faculty of Mass Communication, Cairo University, \\ Egypt
}

\begin{abstract}
Film production is a reflection of the elements of social, political and economic life. If books are the written memory of nations, we can consider cinema as the visual memory. Cinema can play a role of soft power also, specially political cinema, it works as a weapon in the filmmaker's hands directed towards political power. The research problem of this study focuses on a major question which is: How has the Egyptian cinema presented the Egyptian political reality under the rule of two presidents Jamal Abdel Nasser and Anwar Sadat?. This study is based on survey method. The sample of the study consists of forty political films which were the results of the comprehensive survey. Content analysis was used to analyze the forty political films which were either produced during Nasser's and Sadat's era or after this period. The study reached that the political rule of President Abdel Nasser was characterized by seeking the country's interest equally with chaos at the same time. The rule of President Sadat was characterized by seeking the country's interest followed by the rule of law. The cinema gave a positive image of The Presidents themselves.
\end{abstract}

Keywords: Nasser, Sadat, Political, Cinema

\section{Introduction}

The political reality of societies varies and changes according to the different events and circumstances these societies live in. The most prominent political events as colonialism, revolutions, changing regimes and wars that countries may witness throughout their history usually create a distinct political reality for those countries. This political reality has the greatest impact on the lives of its people in various aspects of their lives (social, economic, artistic...). Film industry is never separated from that in general; the film production is a reflection of social, political and economic life, influenced by what happens in the society and the world. Film production, specially political films which discuss the political current events and which depict the past, is obviously related and influenced by the political reality. The importance of this cinema is that, it can make us know more about our own present and see a lot about the memory of our society, our history, as well as the history of other societies.

Many Egyptian and foreign historians and researchers believe that through the audiovisual revolution that swept up the world, feature films that depict real and past political events, have been competing with academic and scientific works in history. They added that historical documentation now is no longer exclusive to historians and academic scholars, as they believe that cinema can also document important events and make them alive.

Egypt is one of the most important countries with a strong political history. In modern history, the revolution of July 1952 produced a lot of important political events that filmmakers introduced in Egyptian films. Depicting the two periods of rule, President Jamal Abdel Nasser (1956:1970) and President Mohamed Anwar Sadat (1970: 1981), these films depicted important historical eras, including the pros and cons of each. The filmmakers presented explanation, analysis and criticism stemming from their opinions of these two periods, which may change, correct or reinforce the view of many, specially youth, towards these two periods of government. 
This study focuses on a main question: How has the Egyptian cinema presented the Egyptian political reality under the rule of two presidents; Jamal Abdel Nasser and Anwar Sadat? in order to determine the features of political life in these two periods as presented by the Egyptian cinema and the reflection of these features on the social life of the Egyptian people.

These two periods were specifically chosen for the following reasons:

1- These two periods followed the revolution of July 1952 directly and witnessed the direct repercussions of the revolution and also the political and economic changes in the Egyptian society after the transformation of the regime from the royal political system to the presidential system.

2- These two periods are over thirty years old and have become a historical period that can be judged with a clearer view. This cannot be applied on Mubarak's period of rule which is very recent in the Egyptian history.

3- The events of these two periods can be attributed to the two presidents, and this is not the case in the period of President Najib (1953:1954), where the actions were attributed to the Revolutionary Command Council.

This study focused on the films produced under the two periods of government and beyond because by reference to the previous studies that are related to the subject of the current study, their findings were divided into two streams: The first indicated that the films which deal with real events and were produced at the same time of these events have the warmth of the moment and the vitality of the sense of living reality, which cannot be found in films that were produced in the nineties and beyond about the sixties and seventies. The other trend indicated that films which address the historical event in the cinema at the time of occurrence or after a short period make the vision incomplete because the circumstances of the event and its details are not clear yet. This trend also noted that the writers need some time to digest events and create a clear vision of them. Under these results, it was better to combine the films produced under the two terms of government, and the films produced for the two periods after the end of the two terms, in an attempt to combine the advantages of each group.

This type of studies links between cinema as an artistic media tool, politics, and history at the same time.

This paper presents an explanation of the objectives, reviews the results of the previous studies, the questions of the study, methodological procedures, sample selection, results, conclusion, discussion and references.

\section{Objective}

The main objective of this study is to analyze the Egyptian political films that treated the political reality of Egypt during the reigns of Nasser (1956:1970) and Sadat (1970:1981) in order to identify the features and characteristics of political life in the Egyptian society during that period as reflected by the Egyptian cinema to answer questions about:

1- The images of the two presidents.

2- The types of the role of the two eras

3- People's orientations towards the two eras .

\section{Literature Review}

- A review of previous studies about political cinema including Egyptian and Foreign studies showed five main points these studies revolve around: 


\section{1- Cinema effect:}

Many of the previous foreign studies focused on the importance of cinema as a means of communication and its effects. They clarify that cinema is a double-edged political weapon; either in the hands of the ruling authority and the conflicting political currents of power that use it to achieve their objectives, or as a political weapon that offers people what political regimes do not like to offer. Political leaders believe that cinema is capable of changing public opinion and political ideas, So governments are always trying to control it. The Egyptian studies did not discuss clearly the impact that political cinema can have. (Hesling,2001; Renkus,2007; Donnelly,2008 ; Sharma,2009; Stone,2009; Allison,2010; Arsenjuk,2010; Jones,2015; Gamil,2016; Pisters,2016).

\section{2-Political cinema follows the ideology of the existing regime:}

Foreign and Egyptian studies have almost equally agreed that political cinema largely follows the dominant political and ideological trends in society (Farag, 2001; Alagamy, 2004; Ali, 2010; Alnagar, 2011; Chae 2011; Frame, 2012; Jones,2015).

\section{3- Cinema acts as a historical document:}

Foreign and Egyptian studies have agreed on the importance of cinema in dealing with the past and the history of nations. Some consider it as a historical document in the case of the extreme historical accuracy in presenting events of the past, where the ability of the cinema to change wrong trends and stereotypes of the past and keep it alive. (Alsherbiny, 1999; Hesling, 2001; Renkus, 2007 ; Ahmed, 2008; Stone,2009; Allison,2010; Chae 2011; Alsayed, 2012; Pisters,2016 ).

\section{4- Political cinema often attacks the past:}

Egyptian studies agreed that political cinema cannot criticize the political regimes. Only after the demise of power, the previous regime is often presented in bad way as opposed to the advantages of the current regime (Nasr, 1984; Sharaf Alden, 1990; Qassem, 1995; Ali, 2010), but foreign studies disagreed with that and proved it by the American films which presented the previous American presidents as better than the current serving one, which doesn't happen often in the Egyptian cinema. (Renkus, 2007; Donnelly, 2008; Frame, 2012).

\section{5- The ability of cinema to express the reality of living:}

Egyptian studies differed in their findings about the ability of cinema to express the reality of living between full capacity (Alagamy, 2004; Saad, 2008; Alnagar, 2011) and the opposite (yassin, 1996; Alsayed, 2012; Qazzaz, 2014). Foreign studies have rarely discussed this point.

We conclude that literature in the field indicate that the relationship between cinema and politics is a relationship of mutual influence and that cinema was better able to correct wrong images and present the past than present current reality in a manner appropriate to it. The cinema, whether we like it or not, follows the dominant ideology and the political regime. In Egypt, it can often criticize political regimes only under subsequent political regimes.

\section{Research questions}

1-What was the source of Egyptian film stories that dealt with the political reality of the two periods of rule of Presidents Abdel Nasser and Sadat? 
2-What were the political events presented by these films?

3-What were the political and social issues presented by these films?

4-How did these films show the image of political life in each period of the two periods?

5-What is the difference in the treatment of these two periods in the films produced under the two terms of the government, and which were produced after the end of the two terms?

6-What were the goals sought by the dramatic treatment of the films under study?

7-What were the values defended by the studied films?

\section{Methodology}

This study is based on survey method. The sample of the study consists of forty political films produced since 1956 till 2016 which were the results of the comprehensive survey. Content analysis was used to analyze the forty political films..

\section{Results And Discussions}

The following pages include the results of the analysis of 40 political films:

At the beginning, the Egyptian cinema dealt with the rule of President Abdel Nasser in twenty-three films, as opposed to nine films of President Sadat and eight films dealing with both eras together.

\section{Question 1: What was the source of the studied films Stories?}

Especially written for

cinema $67.5 \%$

Literary Story $\mathbf{2 5} \%$

Real incident $5 \%$

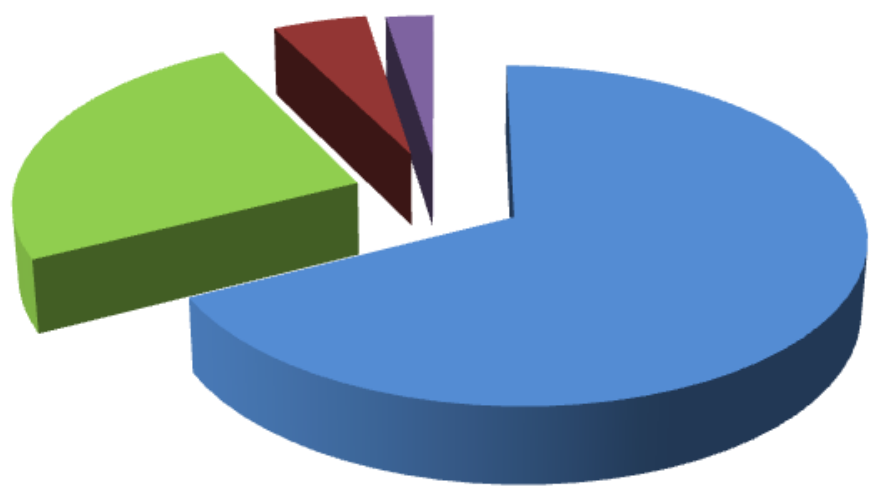

Figure 1 Source of the studied films Stories. 
It is clear from the previous figure -Figure 1- that the largest proportion of the source of the film stories was the story written specially for cinema which presented Twenty-seven films. This was followed by the literary stories which were ten films, including six films by the writer Naguib Mahfouz. Then, the real incident were 2 films, and finally the story of a play was 1 film.

\section{Question 2: What were the political events presented by these films?}

The Egyptian cinema dealt with seventeen events that belonged to the two periods together; ten of which were specific to the era of Abdel Nasser. They were ordered according to the majority of their appearance as follows: (The setback of 5 June 1967 and its effects and abdication of Nasser, The Tripartite Aggression on Egypt October 29, 1956, The War of Attrition (1967:1970), Nationalization of the Suez Canal 26 July 1956, Construction of the High Dam beginning in 1960).

Then came ( the laws of agricultural reform, the Egyptian intervention in the war in Yemen, And the death of Abdel Nasser) with equal percentage .Then, there was the event of unity between Egypt and Syria and then the dismissal of judges, in exchange for seven events for the period of President Sadat (Victory of October 1973, Elimination of power centers, the policy of an open economy at the end of 1973, 1977 uprising due to the abolition of subsidies on basic commodities. Then, Nixon's visit to Cairo which coincided with the Camp David Accords, and Sadat's assassination happened only once in the sample films).

The setback of 5 June, 1967 in Nasser era was the first set of events treated by the Egyptian cinema. It was given special attention by filmmakers through presenting the events of the setback and its aftermath. It was also presented as the worst event in the modern history of Egypt since the revolution of July, 1952. On the other hand, films considered the victory event of October 1973 as the most positive event in that period, and it belongs to the era of Sadat regardless of poor treatments the event has been addressed in all films.

The Egyptian political cinema didn't support the idea of the war, even if the goals of the war were noble, as in the film "Fire Love" which dealt with the event of triple aggression, and the films "The Fear" and "The Sons of Silence" which dealt with the setback and the war of attrition. These showed that the Egyptian cinema did not support the idea of war in general, and the war was presented as a means of defending and retrieving rights.

\section{Question 3 :What were the political and social issues presented by these films?}

The filmmakers worked hard to present the political issues that shaped the political life in each era, as well as the social issues that emerged from them. Twelve political issues emerged. The first political issues in the era of Nasser were patriotism, then struggle, then independence, then political corruption, then freedom. In The era of Sadat the struggle came first, then patriotism, then independence equal to the hope of change, methods of prevention and oppression), and then came political corruption which was equal to freedom. In the era of Nasser, there was also a clear absence of law enforcement. It is the opposite of Sadat's era, which clearly showed the rule of law. The first factor causing the difference here is the disappearance of the influence of power centers in Sadat's era which allowed law enforcement in society which was a main reason for the nonactivation of the law in the era of Nasser. 


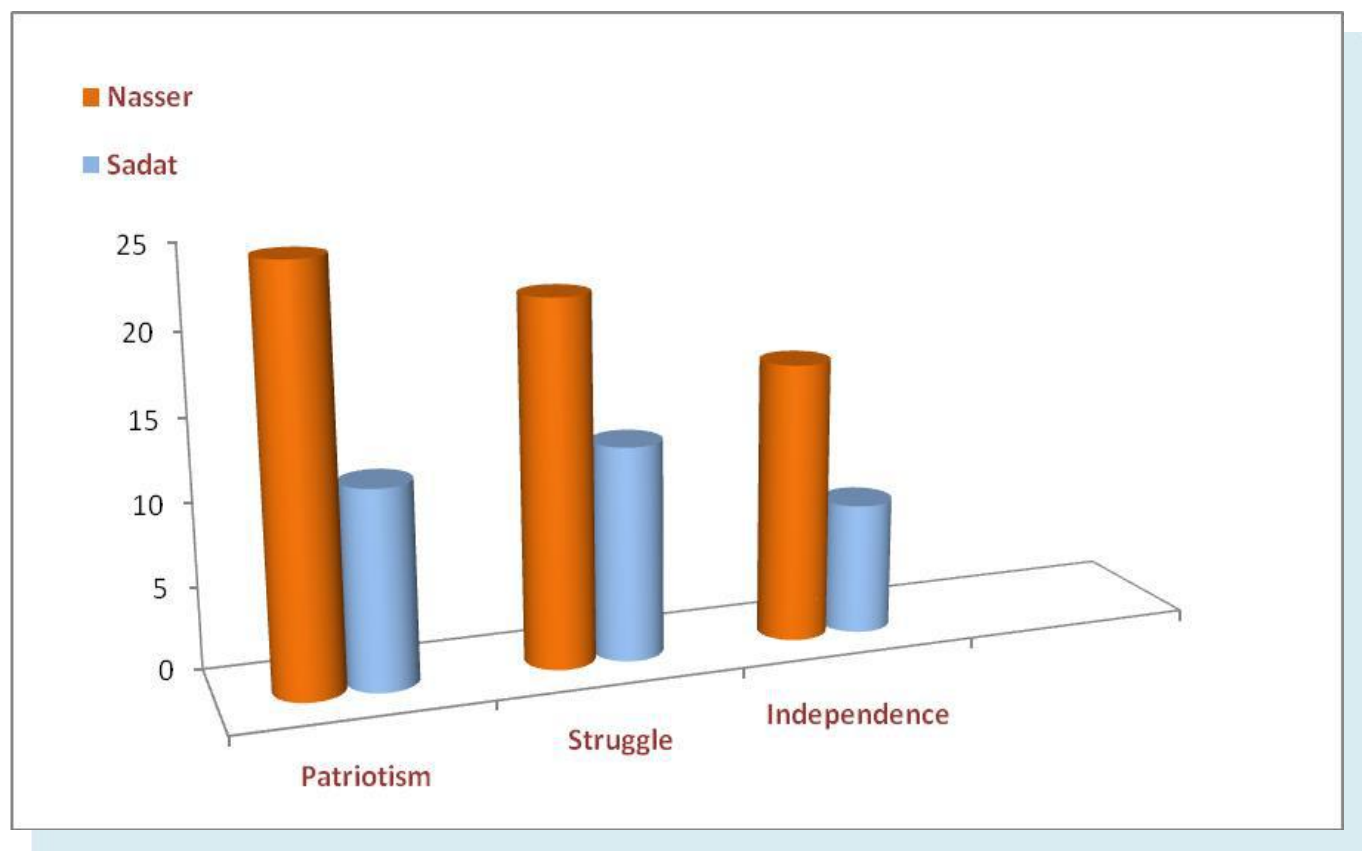

Figure 2 Comparison of the first political issues in the era of Nasser and Sadat.

The social issues arising from the political issues were ten, most of which were problems and negative events suffered by the society. The social issues during Nasser's period were: social corruption, poverty, marriage, low standard of living and then came education as equal as the urge to work, and then comes the government routine which was equal to the search for jobs. The era of Sadat began with social corruption which emerged as the remains of the Nasser era, as equal as poverty. Then came the low standard of living followed by marriage, and then came education, the routine of the government and the search for jobs with equal percentages.

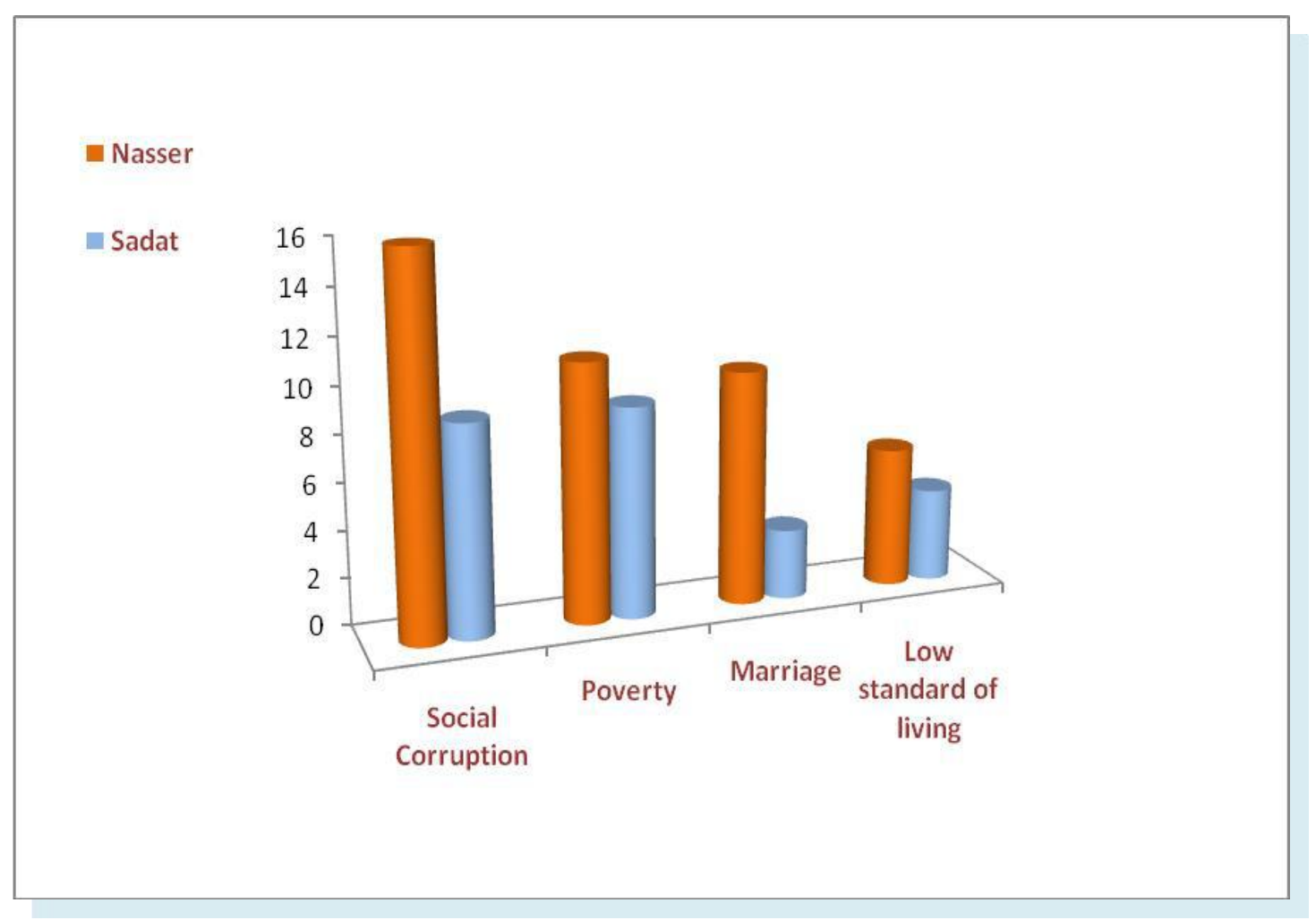

Figure 3: Comparison of the first social issues in the era of Nasser and Sadat. 


\section{Question 4: How did these films show the image of political life in each period of the two periods?}

The policy of Nasser's rule was characterized by the pursuit of homeland interests, chaotic and indiscriminate with equal percentage, then came repression, then injustice and then achieving personal interests.

The policy of Sadat's rule was characterized by the pursuit of homeland interests, then the rule of law, and then attempts to change for the better, and then achieving personal interests which came equal to the establishment of internal national projects, freedom and justice.

Note that although the Egyptian cinema presented the policies of President Nasser's rule characterized by chaos and randomness, repression and injustice as basic features, the achievement of the interest of the country was the first goal even if not done in the best way to deal with opponents and critics.

Although President Sadat did not have the same popularity of President Nasser, the films that dealt with the policy of Sadat's rule showed a better picture of the policies of his rule.

President Abdel Nasser was more in touch with the people from President Sadat, and the cinema showed him permanently communicating with the Egyptian masses in live meetings. The cinema did not record public meetings of President Sadat which was often in the House of Representatives.

The two eras agreed that the three main factors influencing political life with the ruling president is: (media, citizens and military establishment). These three elements were the most influential political elements in political life in the two eras and emerged in close percentage specially the media and citizens.

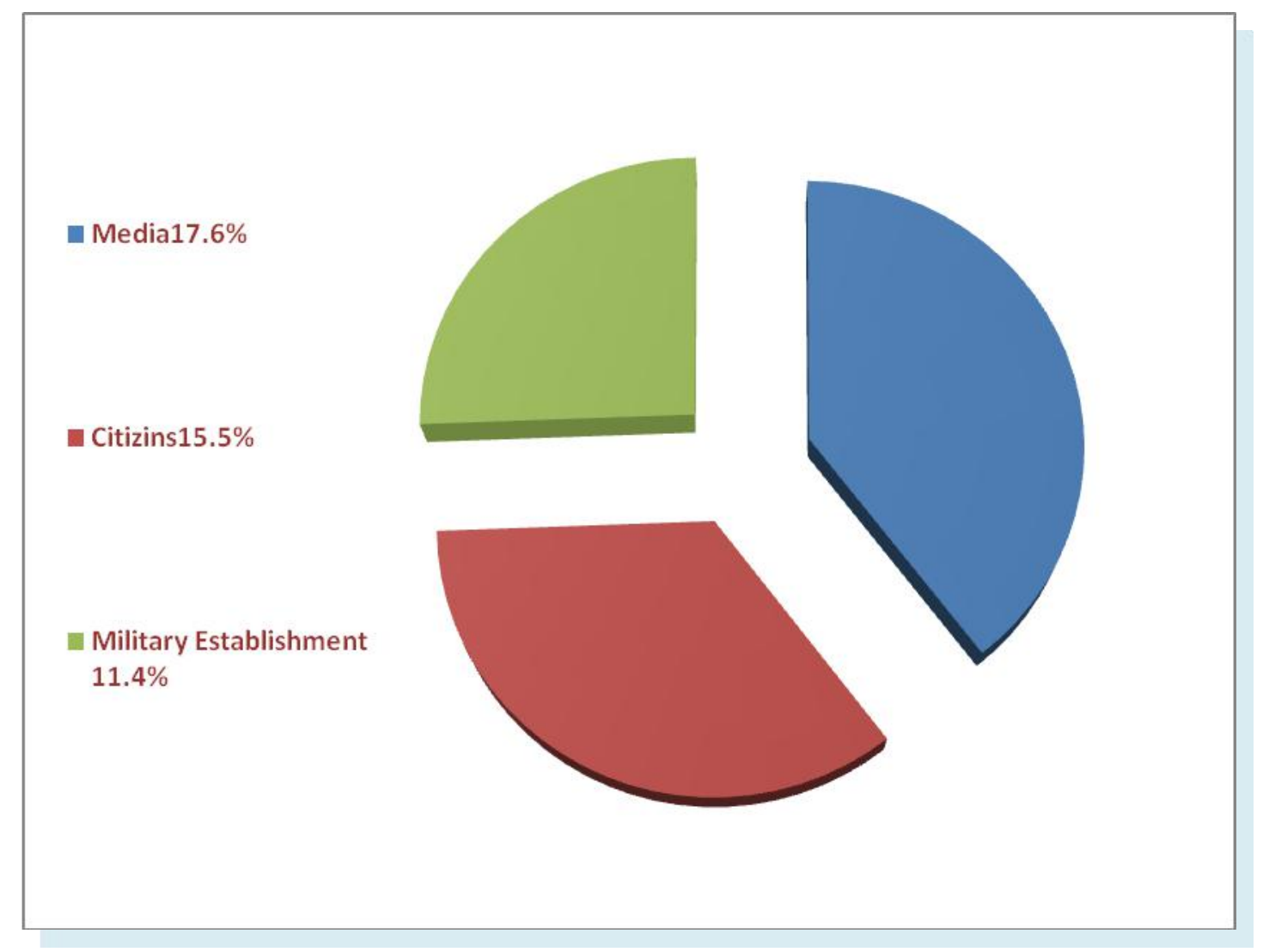

Figure 4 The three main factors of political life in the two eras.

The first reason for President Nasser's support was his patriotism, while national achievements were the first reason for President Sadat's support. 
The main reasons for anger with the ruling regime of Nasser's era were (low standard of living, then harm from government policies, the suppression of freedoms, the absence of law, and mismanagement). While the main reasons for anger in era of Sadat were the harm from the government's policies of governance, the low standard of living, the failure to declare a policy of governance for the people, and the suppression of freedoms).

The repression was the basic method of dealing of the Nasser regime with the opposition, as well as for the Sadat regime. However, in the Sadat era there was an attempt to make decisions to appease the opposition.

The positive image of the two presidents presented in these films was above the negative, where there was a sort of separation between the president's person and the policies of the power-holders.

The main popular demand in Nasser's era was to live in a better reality, while in the era of Sadat it was victory over the enemies.

Question 5: What is the difference in the treatment of these two periods in the films produced under the two terms of the government, and which were produced after the end of the two terms?

At first, identifying the characteristics of the films in the study sample, it was found that twenty-seven films were produced under the two terms of study, of which only seven were produced under the reign of President Abdel Nasser, compared to twenty films produced under President Sadat's reign. Thirteen films were produced after the end of the two terms, indicating that the film production movement was more active in the era of President Sadat.

As for Nasser's era, most of the supporting films were produced during his time. Egyptian cinema only produced two films that attacked and criticized Nasser's era during his reign (Case 68, Miramar 1969), which was near the end of his reign and after the setback.

The cinema did not dare to attack the era of Nasser fiercely until after the end of his reign, and the largest number of films that opposed and criticized the rule of Nasser were made during the rule of Sadat, where eleven films attacked Nasser's era under Sadat's rule; that was not repeated again until now"

Cinema was more active and free in the era of Sadat and gained the ability to attack the existing regime, and has been able to present pro-opposition films. Films that criticized Sadat's era and that were made in his era, were more than those made after the end of his term.

\section{Question 6: What are the goals sought by the dramatic treatment of the films under study?}

The three main goals presented by the Egyptian cinema films in the two eras were documenting and narrating the political events, then highlighting the Egyptian identity, and then presenting the disadvantages of periods of government. 


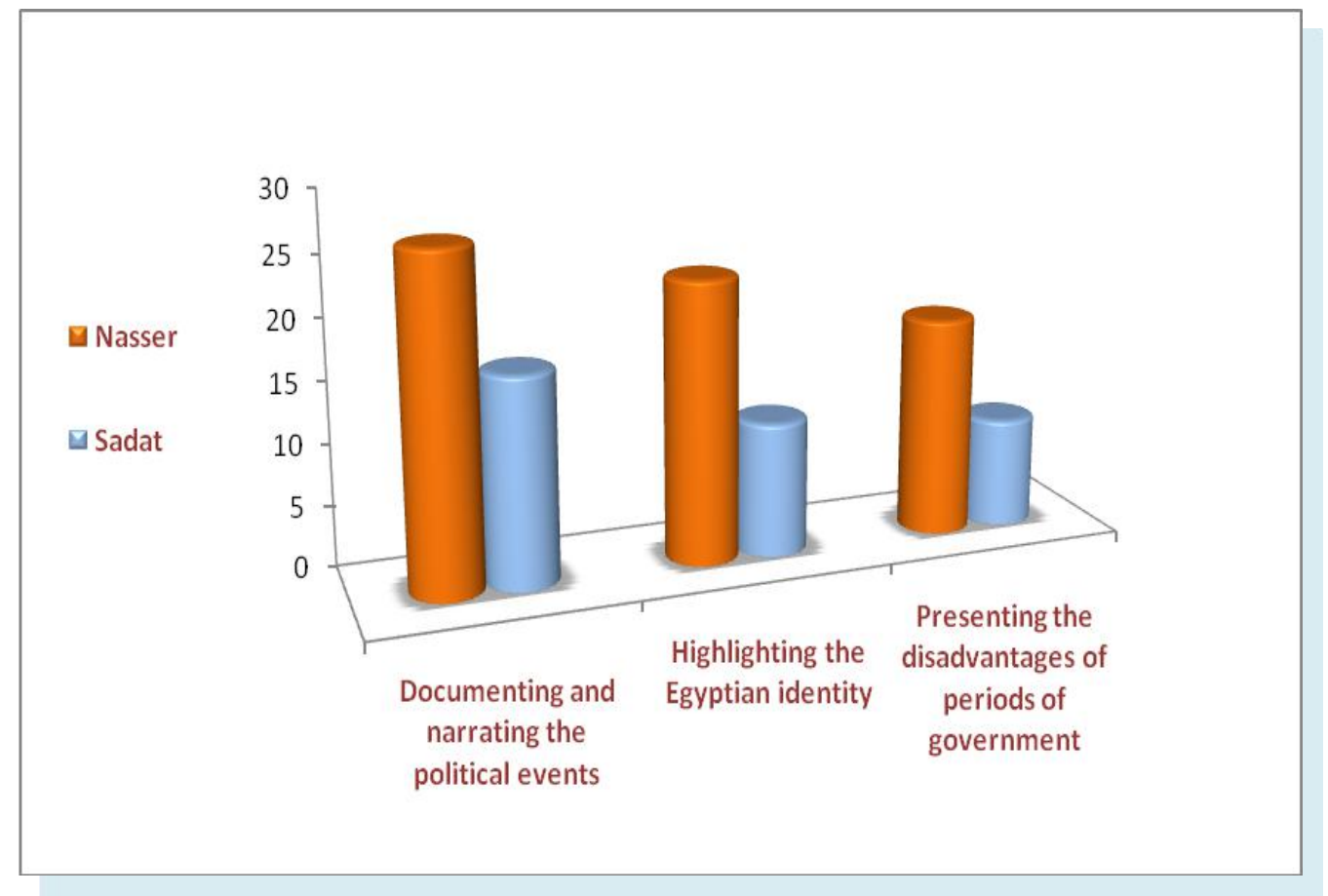

Figure 5 Goals presented by the Egyptian cinema films in the two eras.

\section{Question 7: What are the values defended by the studied films?}

Egyptian political cinema in the two eras defended many positive values, which amounted to fourteen values. Courage came first, then patriotism and then value of struggle, as well as the negative values that prevailed during that period. Seventeen negative values were presented, where the value of moral corruption and then exploitation were most obvious during that period.

\section{Conclusion}

Eventually, and after presenting the results, we can say that, what was presented in these films is the responsibility of the makers of those films. In case of strict accuracy in the narration of events, film makers contribute in the formation of the memory of the nation, while in the case of inaccuracy they contribute in the loss of truth and history. In view of the importance of political cinema and its ability to keep history alive as well as its ability to change and correct the wrong images, Yes, cinema can make real changes,. In case that there is a regular production of political films that analyze and comment on political events and decisions of political leaders. free cinema as much as possible does not implement the ideologies of the existing system, serious filmmakers to play their societal role in delivering the voice of the masses to political leader and explain the views of leaders to the people. In this case, cinema will be seen as a soft power, It will say everything that political leaders do not like people to know. People will wait for cinema to see what they cannot see in reality.

\section{Acknowledgement}

I would like to thank Allah first for helping me, then thank my small family, my husband Muhammad and my son Selim, my great family, my father, mother and sisters, and thank my husband family, and my professors Dr. Mona Alhadidy \& Dr.Salwa Imam for their permanent support, thank my friend Sara khater and all my friends. Thank you so much. 


\section{References}

1-Ali Shawki Ali,2010, The influence of social changes on the Egyptian narrative film from 1952 to the end of the twentieth century, Master Thesis ,Cairo, Academy of Arts, High Institute of Cinema.

2-Ashley Minix Donnelly, 2008 "Blank Power: The Social and Political Criticism of Blank Fiction and Cinema", PHD Thesis, University of South Florida.

3-Ashraf Ahmed ,2008, The historical event and the cinematic approach: A study in the historical scenario, PHD Thesis ,Cairo, Academy of Arts, High Institute of Cinema.

4-Asseem Yassen , 1996, The role of the Arab historical films in presenting the history of the Arab nation, Master Thesis , Cairo University, Faculty of Mass Communication, Radio and Television Department.

5-Ayah Gamil, 2016, Addressing the cinematic drama of political values and its relation to shaping public attitudes toward these values, Master Thesis, Cairo University, Faculty of Mass Communication, Radio and Television Department.

6-Ayman Elsherbiny,1999, Historical drama in television and its role in spreading the historical awareness, Master Thesis, Cairo University, Faculty of Mass Communication, Radio and Television Department.

7- Christopher D. Stone,2009, "Fields Of Dreams: The Image Of The Sixties In American Cinema", PHD Thesis, Indiana University.

8-Diaa Elden Mohamed, 2012,The problematic of the production of historical drama in Egyptian cinema , PHD Thesis, Cairo, Academy of Arts, High Institute of Cinema.

9-Dorreyah Sharaf Alden,1990, Political, economic and social changes in Egypt and its impact on feature films in the period 1961-1981, PHD Thesis, Cairo, Academy of Arts, High Institute of Cinema.

10- Essam Nasr, 1984, Cinema and its ability to express political events, Master Thesis , Cairo University, Faculty of Mass Communication, Radio and Television Department.

11- Gregory Frame,2012, "The American President In Film and Television", PHD Thesis, University of Warwick.

12-Hassan Qazzaz,2014, The Egyptian cinema treatment of the Palestinian cause, and its influence on the Attitudes of Egyptian University Youth, Master Thesis ,Cairo University, Faculty of Mass Communication, Radio and Television Department.

13- Lauren Amelia Jones, 2015, "Il Cinema Ele Ideologle Politiche Alla Mostra Internazionale D'arte Cinematografica Di Venezia", Master Thesis, Georgetown University.

14- Luka Arsenjuk,2010, "Political Cinema: The Historicity of an Encounter", PHD Thesis, Duke University.

15- Miriam Sharma, 2009, Censoring India: Cinema and the Tentacles of Empire in the Early Years, South Asia Research, SAGE, Vol. 29, No.1, 41:73.

16-Mohamed Alagamy, 2004, The economic changes in Egypt and their impact on the film industry in the second half of the tenth century, PHD Thesis, Cairo, Academy of Arts, High Institute of Cinema.

17-Mona Farag,2001, The censorship criteria for the Egyptian film in cinema and television, , Master Thesis , Cairo University, Faculty of Mass Communication, Radio and Television Department.

18-Patricia Pisters, 2016, The Filmmaker as Metallurgist: Political Cinema and World Memory, FilmPhilosophy, Volume 20, Issue 1, 149:167.

19-Safaa Alnagar,2011, political cinema treatment to political human rights, Master Thesis, Cairo University, Faculty of Mass Communication, Radio and Television Department.

20-Safaa Saad,2008, The treatment of short feature films presented by the Egyptian Television for issues of Egyptian society, Master Thesis, Cairo University, Faculty of Mass Communication, Radio and Television Department.

21-Sherin Qassem,1995, Problematic political film concept, Master Thesis ,Cairo, Academy of Arts, High Institute of Cinema.

22- Tanine Allison, 2010, Screen Combat: Recreating World War II in American Film and Media, PHD Thesis, University of Pittsburgh.

23- Willem Hesling ,2001, The past as story The narrative structure of historical films, European Journal of Cultural Studies, SAGE, Vol.4, No.2, 189 : 205. 
Proceedings of the $5^{\text {th }}$ World Conference on Media and Mass Communication, Vol. 5, Issue 1, 2019, pp. 131-141

24- William A. Renkus, 2007, American Political Films: 1968-1980, PHD Thesis, University of Florida.

25-Young Eun Chae, 2011 , Screening the Past: Historiography of Contemporary South Korean Cinema19982008 ", PHD Thesis, University of North Carolina. 